\title{
Sunshine Hours and Utilization of Benzodiazepines
}

\author{
Srđan Z. Marković1,2, Đura J. Nakarada ${ }^{1}$, Miloš D. Mojović1, \\ Mirjana M. Beljićs, Mira H. Vuković4 , Dragana A. Kastratović ${ }^{2}$ \\ ${ }^{1}$ Faculty of Physical Chemistry, University of Belgrade, Center for Physical Chemistry of Bio- \\ logical Systems, Belgrade, Serbia \\ ${ }^{2}$ Clinical Centre of Serbia, Belgrade, Serbia \\ ${ }^{3}$ Pharmacy Belgrade, Belgrade, Serbia \\ ${ }^{4}$ QA Department, Health Centre Valjevo, Valjevo, Serbia
}

\section{SUMMARY}

Introduction: Benzodiazepines belong to the group of anxiolytic sedatives and the most prescribed drugs in the world. The authors conducted this pilot study based $\mathrm{n}$ large number of patients reports that they were less anxious and felt better overall by migrating to sunnier environments.

Aim: We estimated the impact of the total sunshine hours per month on daily exposure of the population to benzodiazepine anxiolytic on a monthly basis in the Republic of Serbia. Material and Methods: We conducted a retrospective academic IV phase study, which tested the correlation of time series of monthly sold benzodiazepine anxiolytics in pharmacies and total sunshine hours per month in the Republic of Serbia, from January 2014 to May 2019.

Results: According to the seasons, we did not find any difference in the increase of the population exposure to benzodiazepines. A difference was found between bromazepam consumption compared to cumulative monthly. Bromazepam consumption was negatively correlated with the cumulative monthly sunshine hours. The cutoff value for bromazepam was 131.45 cumulative monthly sunshine hours.

Conclusion: This is the first pharmaco-epidemiologic study to prove that the population's exposure to benzodiazepines, in addition to the implicit health and economic effects on physicians' prescribing habits for these drugs, can be independently linked to the cumulative effects of monthly sunshine hours on the population. No difference in benzodiazepine consumption was found in relation to the seasons (spring/summer vs autumn/winter). In months where sunshine hours was $\geq 135.45$, the need for bromazepam was significantly reduced. Seasonal variation of climatic effects of total monthly sunshine hours is significantly correlated with the population's need for benzodiazepines with anxiolytic effects longer than 12 hours.

Keywords: Benzodiazepines, Sunny Days, Climate, Utilization, Anxiolytics 


\section{INTRODUCTION}

Benzodiazepines belong to the group of anxiolytic sedatives and the most prescribed drugs in the world [1]. Research and monitoring of benzodiazepine consumption / use is usually done in relation to the economic parameters that determine the stability and efficiency of the health system of countries. An academic investigator initiated, pharmaco-epidemiological difference-in-difference time series analysis of population exposure to benzodiazepines between the three, geographically close Balkans countries (Slovenia, Serbia, Croatia) with varying degrees of socioeconomic development has been carried out, at the annual level, during the study period from January 2014 to December 2018, compared to Slovenia, Serbia and Croatia had higher DIDs, from 5 fold (Croatia) to 6 fold (Serbia), for all benzodiazepines in total [2]. Papers that can be found in the scientific literature describe the effects in relation to pharmacokinetic parameters, product quality, price, economic parameters of development and stability of the place of residence, personal life circumstances and psychiatric history of people $[3,4,5,6]$. The authors conducted this pilot study based on reports from a growing number of patients that they have become less anxious and feel better overall by migrating to sunnier environments.

\section{AIM}

We estimated the impact of the total sunshine hours per month on daily exposure of the population to benzodiazepine anxiolytic on a monthly basis in the Republic of Serbia.

\section{MATERIAL AND METHODS}

We conducted a retrospective academic IV phase study focusing on the correlation of time series of monthly sold benzodiazepine anxiolytics in pharmacies and total sunshine hours per month in the Republic of Serbia. The period of research was from January 2014 to May 2019.

Data on sold anxiolytics were obtained from the IQIA Institute for Human Data Science [7], while data on the total sunshine hours per month were taken from the official "Weather Online" website for six cities in the Republic of Serbia [8]. Two cities in the central part of the country were selected - Belgrade $\left(44^{\circ} 49^{\prime} 00\right.$ „N, $020^{\circ} 28^{\prime} 00^{\prime}$ E) and Kraljevo $\left(43^{\circ} 43^{\prime} 25, \mathrm{~N}, 020^{\circ} 41^{\prime} 13^{\prime \prime} \mathrm{E}\right)$ and one of the cities on the outskirts of the country, sorted by geographical location: north - Sombor $\left(45^{\circ} 47^{\prime}\right.$ $\left.00, \mathrm{~N}, 019^{\circ} 07^{\circ} 00^{\prime} \mathrm{E}\right)$, south - Leskovac $\left(43^{\circ}\right.$ $00^{\prime} 00, \mathrm{~N}, 021^{\circ} 57^{\prime} 00^{\prime}$ E) , west - Valjevo ( $44^{\circ}$ $16^{\prime} 00, \mathrm{~N}, 019^{\circ} 53^{\prime} 00^{\prime}$ E) and east - Negotin $\left(44^{\circ} 13^{\prime} 00, \mathrm{~N}, 22^{\circ} 31^{\prime} 60^{\prime} \mathrm{E}\right)$.

\section{Variables}

On a monthly basis, data on sold anxiolytics included: the type of active ingredient, the amount of active ingredient, unit (packs/ bottles), the number of pharmaceutical forms per pack unit. Publicly available data on the population of the Republic of Serbia were taken from the Statistical Office of the Republic of Serbia [9]. Consumption of all medicines according to their generic ingredients was transposed as a defined daily dose per 1000 inhabitants per day (DID) according to the following formula: $\mathrm{DID}=(\mathrm{U} \times \mathrm{PF} \times \mathrm{Q} \times 1000) /(\mathrm{DDD} \times$ inhabitants $\times$ number of days in each month), where U - units (packs / bottles), PF - number of pharmaceutical forms per unit, Q - amount of active ingredient in each pharmaceutical form. DID is used to measure the daily exposure of the population to a particular drug.

The total DID was calculated by summing the DID values of each drug. Also, special DID values were calculated for benzodiazepines with anxiolytic activity $>12$ hours (diazepam and bromazepam) as well as for benzodiazepines with anxiolytic activity $\leq 12$ hours (lorazepam and alprazolam). Although prazepam has a very long-lasting anxiolytic effect (90 hours), it was not included in the benzodiazepine group with anxiolytic effect $>12$ hours, because the average daily exposure of Serbian population to prazepam was negligible over the entire study period.

The total sunshine hours per month for Serbia were calculated as the average of the total sunshine hours per month of six selected Serbian cities. After data processing, one dummy variable was constructed according to the cut of value obtained for the total sunshine hours per month between springsummer months (from April to September) versus autumn-winter months (from October to March). 


\section{Statistical methods}

The data for continuous variables are described by the arithmetic mean as a measure of the central tendency and standard deviation as a measure of variation of the data set. Analysis of differences between groups of parameter data was performed using independent samples Mann-Whitney U test.

Cut of value for newly constructed dummy variable for the discrimination of high sunshine (the total sunshine hours per month in spring-summer period) versus low sunshine (the total sunshine hours per month in autumn-winter periods), was estimated by receiver operating characteristic (ROC) procedure. Cut of value, sensitivity, specificity, positive predictive value, and negative predictive value were obtained by applying maximum Youden index: $J=\max (\mathrm{SEi}+\mathrm{SPi}-1)$ where SEi denotes sensitivity and SPi denotes specificity for each potential cut of value of the resulting variable.

Stepping method criteria were based on the probability of $\mathrm{F}$, where variables with a probability less than 0.05 were retained, while variables with a probability greater than 0.10 were excluded from the model. The linearity assumption was checked by constructing a scatter plot diagram for each independent variable. The diagnosis of collinearity between the predictors in the linear regression model was done by the arbitrary assessment of the conditional index and the variance inflation factor (VIF). The absence of the multicollinearity was defined by a conditional index less than 30 and VIF value less than 3 . The Durbin-Watson statistic was used to arbitrarily evaluate the independence of the residuals. Homoscedasticity was formally tested by the Breusch-Pagan test with F statistics. In the case of heteroscedasticity, a natural logarithmic transformation of the data was performed in order to homogenize the variance of the residuals. The normality of the distribution of residuals was verified by the Kolmogorov-Smirnov test. Outliers were detected and removed in each particular case where Cook's distance statistic was greater than 1 . The accepted level of significance was 0.05 . The statistical analysis was conducted using IBM SPSS Statistics 20.

\section{RESULTS}

Working towards of our research goal (assessment of the impact of monthly sunshine hours on the monthly exposure of the population to benzodiazepines in Serbia), we first divided the months according to the seasons when it is natural to expect less sunshine autumn/winter (low sunshine) vs spring/summer (higher sunshine) and then we examined the significance of the difference in benzodiazepine exposure between these periods. We did not find any difference in the increase in exposure (or need) of the population for benzodiazepines) (Table 1, 2). Descriptive statistics for continuous study variables for the entire period (from January 2014 - May 2019) are presented in Table 1, while descriptive statistic demonstrating the significance of the differences between data in spring-summer months versus autumnwinter months are shown in Table 2. Among the spring-summer/autumn-winter months, only the total sunshine hours per month were found, where in the spring-summer months the total sunshine hours per month were significantly higher (238.94 hours \pm 55.62 hours) than the autumn-winter months (102.06 hours \pm 41.91 hours) - Table 2. Other variables did not show significant difference between the mentioned groups of months (Table 2).

As we did not find any difference above, we decided to determine exactly what is
Table 1. Descriptive statistics for the total DID of benzodiazepine anxiolytics and the total sunshine hours on monthly basis, all presented by years in the Republic Serbia (January 2014 - May 2019)

DID - defined daily dose per 1000 inhabitants per day $\mathrm{N}$ - number of months SD - standard deviation

\begin{tabular}{|l|c|c|c|}
\hline \multicolumn{1}{c|}{ Variables } & N & Mean & SD \\
\hline The total sunshine hours per month & 65 & 169.45 & 84.46 \\
\hline Diazepam (total DID) & 65 & 24.20 & 8.58 \\
\hline Prazepam (total DID) & 65 & 0.57 & 0.25 \\
\hline Bromazepam (total DID) & 65 & 32.43 & 4.45 \\
\hline Lorazepam (total DID) & 65 & 24.07 & 3.61 \\
\hline Alprazolam (total DID) & 65 & 16.4 & 6.80 \\
\hline All benzodiazepines (total DID) & 65 & 97.78 & 19.45 \\
\hline Benzodiazepines with anxiolytic activity $>12$ hours (total DID) & 65 & 56.63 & 11.38 \\
\hline Benzodiazepines with anxiolytic activity $\leq 12$ hours (total DID) & 65 & 40.56 & 9.17 \\
\hline
\end{tabular}




\begin{tabular}{|c|c|c|c|c|c|}
\hline Variables & Periods & $\mathbf{N}$ & Mean & SD & $\mathbf{p}$ \\
\hline \multirow{2}{*}{$\begin{array}{l}\text { The total sunshine hours per } \\
\text { month }\end{array}$} & spring-summer & 32 & 238.94 & 55.62 & \multirow{2}{*}{$\underline{0.000}$} \\
\hline & autumn-winter & 33 & 102.06 & 41.91 & \\
\hline \multirow{2}{*}{ Diazepam (total DID) } & spring-summer & 32 & 23.03 & 5.30 & \multirow{2}{*}{0.420} \\
\hline & autumn-winter & 33 & 25.34 & 10.83 & \\
\hline \multirow{2}{*}{ Prazepam (total DID) } & spring-summer & 32 & 0.57 & 0.27 & \multirow{2}{*}{0.969} \\
\hline & autumn-winter & 33 & 0.57 & 0.23 & \\
\hline \multirow{2}{*}{ Bromazepam (total DID) } & spring-summer & 32 & 31.86 & 4.55 & \multirow{2}{*}{0.107} \\
\hline & autumn-winter & 33 & 32.99 & 4.35 & \\
\hline \multirow{2}{*}{ Lorazepam (total DID) } & spring-summer & 32 & 23.87 & 3.51 & \multirow{2}{*}{0.397} \\
\hline & autumn-winter & 33 & 24.27 & 3.76 & \\
\hline \multirow{2}{*}{ Alprazolam (total DID) } & spring-summer & 32 & 16.17 & 6.01 & \multirow{2}{*}{0.890} \\
\hline & autumn-winter & 33 & 16.78 & 7.57 & \\
\hline \multirow{2}{*}{ All benzodiazepines (total DID) } & spring-summer & 32 & 95.51 & 15.56 & \multirow{2}{*}{0.358} \\
\hline & autumn-winter & 33 & 99.97 & 22.63 & \\
\hline \multirow{2}{*}{$\begin{array}{l}\text { Benzodiazepines with anxiolytic } \\
\text { activity }>12 \text { hours (total DID) }\end{array}$} & spring-summer & 32 & 54.88 & 8.65 & \multirow{2}{*}{0.300} \\
\hline & autumn-winter & 33 & 58.33 & 13.44 & \\
\hline \multirow{2}{*}{$\begin{array}{l}\text { Benzodiazepines with anxiolytic } \\
\text { activity } \leq 12 \text { hours (total DID) }\end{array}$} & spring-summer & 32 & 40.04 & 8.12 & \multirow{2}{*}{0.657} \\
\hline & autumn-winter & 33 & 41.06 & 10.19 & \\
\hline
\end{tabular}

Table 2. Descriptive statistics for the total DID of benzodiazepines and the total sunshine hours on monthly basis, all presented by spring-summer/ autumn-winter periods in the Republic Serbia (January 2014 - May 2019)

DID - defined daily dose per 1000 inhabitants per day $\mathrm{N}$ - number of months SD - standard deviation the cut-off value in the total number of sunny hours on a monthly basis that separates sunny from gloomy periods, because a season is not equal to quantity of light. Applying the ROC curve, we estimated significant discrimination $(\mathrm{p}<0.0001)$ in the total sunshine hours per month between the autumn-winter and spring-summer periods with a cutoff $\leq 131.45$ hours and with area under ROC curve $=0.973$ (95\% Confidence interval from 0.6960 to $0.8788)$, sensitivity $=81.82 \%(95 \%$ Confidence interval from $64.5 \%$ to $93.0 \%)$, specificity = $100 \%$ (95\% Confidence interval from $89.1 \%$ to $100.0 \%$ ), positive predictive value $=100 \%$ (95\% Confidence interval from $87.2 .1 \%$ to $100.0 \%)$ and negative predictive value $=84.2 \%$ (95\% Confidence interval from $68.7 \%$ to $94 \%$ ).

We further divided the months into groups according to the cut-off value of total monthly sunshine hours of 131.45 , so we examined the difference in benzodiazepine exposure of the population between these groups of months. Between the newly formed group of months with high (the total sunshine hours sunshine hours $>131.45$ ) monthly insolation sunshine hours compared to the group with low (the total sunshine hours sunshine hours $<131.45)$ monthly insolation sunshine hours, a difference was found in total DID for bromazepam, where lower values were estimated in the group of months with higher sunshine hours (31.85 hours \pm 4.19 hours versus 33.31 hours \pm 4.76 hours) (Table 3 ). Here, we found a difference in bromazepam exposure, with higher values for bromazepam exposure in the population were in the period with lower total monthly insolation. This is important, because these results already indicate the rule that the population need for bromazepam increases (one of the benzodiazepines that has an anxiolytic effect equal to or longer than 12 hours) during those months with total sunshine hours lower than 131.45 hours. In other words, we noted that the average population exposure to bromazepam is certainly the highest compared to other benzodiazepines (Table 1 ), and that the need for this drug in the population increases significantly in months with less sunshine hours. Table3).

In the other variables, there was no difference between the newly formed groups with high / low monthly sunshine hours (Table $3)$. In the group of months with high sunshine hours, the average total sunshine hours per month were 226.50 hours \pm 57.80 hours compared to the group of months with low sunshine hours where the average total sunshine hours per month were 83.87 hours \pm 22.10 hours.

One significant multiple linear regression model $(\mathrm{F}=8.175 ; \mathrm{p}=0.001)$ for predictors of the total DID of benzodiazepines with anxiolytic activity $>12$ hours are presented in Table 4. In this model, we found two 
Table 3. Descriptive statistics for the total DID of benzodiazepine anxiolytics, all presented by groups high / low sunshine hours on monthly basis in the Republic Serbia (January 2014 - May 2019)

DID - defined daily dose per 1000 inhabitants per day $\mathrm{N}$ - number of months SD - standard deviation
Table 4. Parameters in the multiple linear regression for predictors of LN (the total DID of benzodiazepines with anxiolytic activity $>12$ hours)

TSH - total sunshine hours per month

SE - standard error

LN - natural logarithm

\begin{tabular}{|c|c|c|c|c|c|}
\hline Variables & $\begin{array}{l}\text { The total sunshine } \\
\text { hours per month }\end{array}$ & $\mathbf{N}$ & Mean & SD & $\mathbf{p}$ \\
\hline \multirow{2}{*}{ Diazepam (total DID) } & High (>131.45 hours) & 39 & 23.05 & 5.06 & \multirow{2}{*}{0.466} \\
\hline & Low ( $\leq 131.45$ hours) & 26 & 25.92 & 12.01 & \\
\hline \multirow{2}{*}{ Prazepam (total DID) } & High (>131.45 hours) & 39 & 0.57 & 0.25 & \multirow{2}{*}{0.941} \\
\hline & Low ( $\leq 131.45$ hours) & 26 & 0.57 & 0.25 & \\
\hline \multirow{2}{*}{ Bromazepam (total DID) } & High (>131.45 hours) & 39 & 31.85 & 4.19 & \multirow{2}{*}{0.042} \\
\hline & Low ( $\leq 131.45$ hours) & 26 & 33.31 & 4.76 & \\
\hline \multirow{2}{*}{ Lorazepam (total DID) } & High (>131.45 hours) & 39 & 23.82 & 3.34 & \multirow{2}{*}{0.302} \\
\hline & Low ( $\leq 131.45$ hours) & 26 & 24.45 & 4.03 & \\
\hline \multirow{2}{*}{ Alprazolam (total DID) } & High (>131.45 hours) & 39 & 16.23 & 5.97 & \multirow{2}{*}{0.952} \\
\hline & Low ( $\leq 131.45$ hours) & 26 & 16.86 & 7.99 & \\
\hline \multirow{2}{*}{ All benzodiazepines (total DID) } & High (>131.45 hours) & 39 & 95.54 & 14.80 & \multirow{2}{*}{0.328} \\
\hline & Low ( $\leq 131.45$ hours) & 26 & 101.13 & 24.82 & \\
\hline \multirow{2}{*}{$\begin{array}{l}\text { Benzodiazepines with anxiolytic } \\
\text { activity }>12 \text { hours (total DID) }\end{array}$} & High (>131.45 hours) & 39 & 54.90 & 8.02 & \multirow{2}{*}{0.236} \\
\hline & Low ( $\leq 131.45$ hours) & 26 & 59.23 & 14.90 & \\
\hline \multirow{2}{*}{$\begin{array}{l}\text { Benzodiazepines with anxiolytic } \\
\text { activity } \leq 12 \text { hours (total DID) }\end{array}$} & High (>131.45 hours) & 39 & 40.05 & 8.08 & \multirow{2}{*}{0.590} \\
\hline & Low ( $\leq 131.45$ hours) & 26 & 41.31 & 10.73 & \\
\hline
\end{tabular}

independent predictors of the total DID of benzodiazepines with anxiolytic activity $>12$ hours. Natural logarithm (LN) of months and LN of the total sunshine hours per months showed the strongest linear correlations with a LN transformed dependent variable the total DID of benzodiazepines with anxiolytic activity $>12$ hours (Figure 1 and Table 4 ). With the LN transformed number of past months (January 2014 to May 2019), the value of the LN transformed value of the total DID of benzodiazepines with anxiolytic activity $>12$ hours increases. In contrast, as the LN transformed value of the total sunshine hours per month increases, the value of the dependent variable decreases (Table 4). The total R squared for the obtained linear regression model was 0.209. The highest conditional index was 22.335 and the highest VIF was 1.002, indicating that there was no multicollinearity in our data set. The Durbin-Watson statistic showed that assumption of independence of residuals had been met, as the obtained value was close to 2 (Durbin-Watson $=2.023$ ). Also, the assumption of homoscedasticity $(F=1.026 ; p=0.306)$ was fulfilled, as well as the assumption of a normal distribution of residuals (KolmogorovSmirnov statistic $=0.092 ; \mathrm{p}=0.200)$. Cook's distance values were below 1 , which indicated that the individual cases did not unduly influencing the model.

Further, with multivariate regression, we wanted to estimate the correlation between the exposure of the population to benzodiazepines by months and additionally with the total number of sunny hours per month. In our

\begin{tabular}{|c|c|c|c|c|c|c|c|c|c|c|}
\hline & \multirow[t]{2}{*}{ Model } & \multicolumn{2}{|c|}{$\begin{array}{l}\text { Unstandardized } \\
\text { Coefficients }\end{array}$} & \multirow{2}{*}{$\begin{array}{c}\begin{array}{c}\text { Standard- } \\
\text { ized Coef- } \\
\text { ficients }\end{array} \\
\text { Beta }\end{array}$} & \multirow[t]{2}{*}{$\mathrm{t}$} & \multirow[t]{2}{*}{ p } & \multicolumn{2}{|c|}{$\begin{array}{c}95.0 \% \\
\text { Confidence } \\
\text { Interval for B }\end{array}$} & \multicolumn{2}{|c|}{$\begin{array}{l}\text { Change } \\
\text { Statistics }\end{array}$} \\
\hline & & B & SE & & & & $\begin{array}{l}\text { Lower } \\
\text { Bound }\end{array}$ & $\begin{array}{l}\text { Upper } \\
\text { Bound }\end{array}$ & $\mathbf{R}^{2}$ & $\begin{array}{c}p \\
\text { (F) }\end{array}$ \\
\hline \multirow{2}{*}{1} & $\begin{array}{l}\text { (Con- } \\
\text { stant) }\end{array}$ & 3.782 & 0.075 & & 50.295 & 0.000 & 3.632 & 3.933 & \multirow{2}{*}{0.146} & \multirow{2}{*}{$\begin{array}{c}0.002 \\
(10.789)\end{array}$} \\
\hline & $\begin{array}{l}\text { LN } \\
\text { (months) }\end{array}$ & 0.074 & 0.022 & 0.382 & 3.285 & 0.002 & 0.029 & 0.119 & & \\
\hline \multirow{3}{*}{2} & $\begin{array}{l}\text { (Con- } \\
\text { stant) }\end{array}$ & 4.168 & 0.189 & & 22.052 & 0.000 & 3.790 & 4.546 & \multirow{3}{*}{0.069} & \multirow{3}{*}{$\begin{array}{c}0.031 \\
(4.893)\end{array}$} \\
\hline & $\begin{array}{l}\text { LN } \\
\text { (months) }\end{array}$ & 0.076 & 0.022 & 0.394 & 3.484 & 0.001 & 0.032 & 0.120 & & \\
\hline & LN (TSH) & -0.079 & 0.036 & -0.250 & -2.212 & 0.031 & -0.150 & -0.008 & & \\
\hline
\end{tabular}




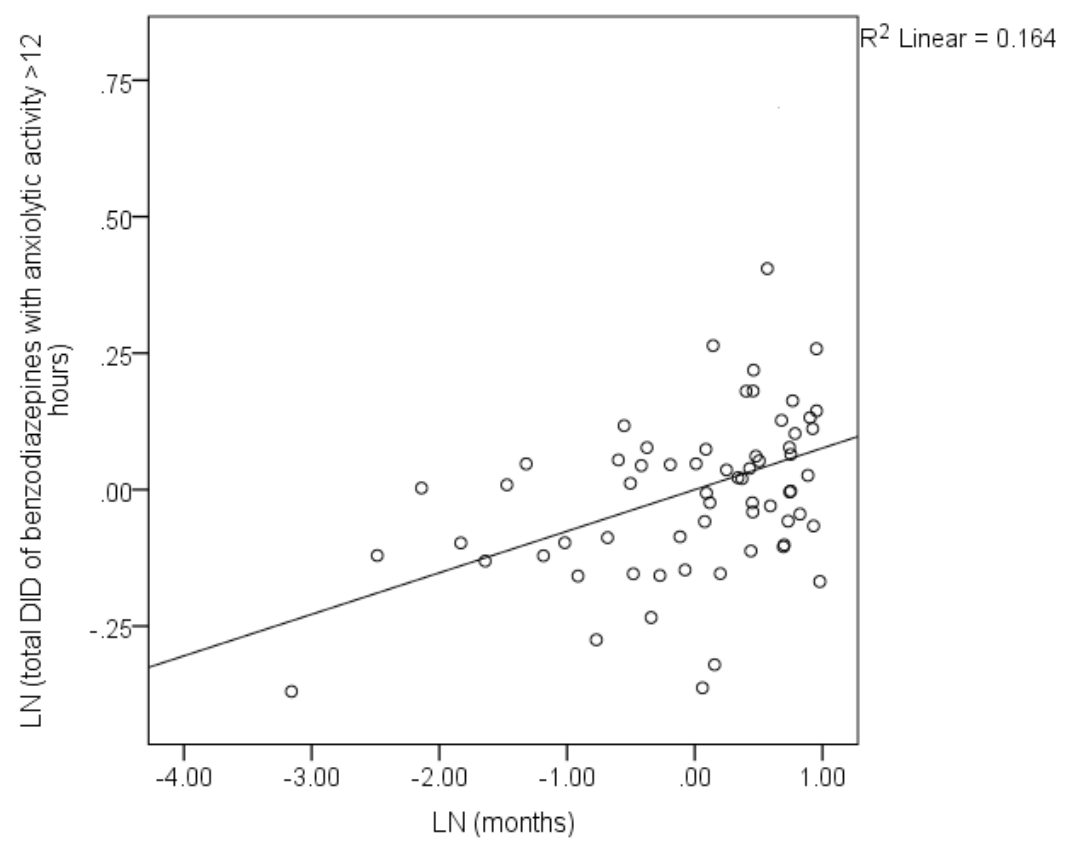

Figure 1. Partial regression plots for predictors of the total DID of benzodiazepines with anxiolytic activity $>12$ hours

DID - defined daily dose per 1000 inhabitants per day LN - natural logarithm

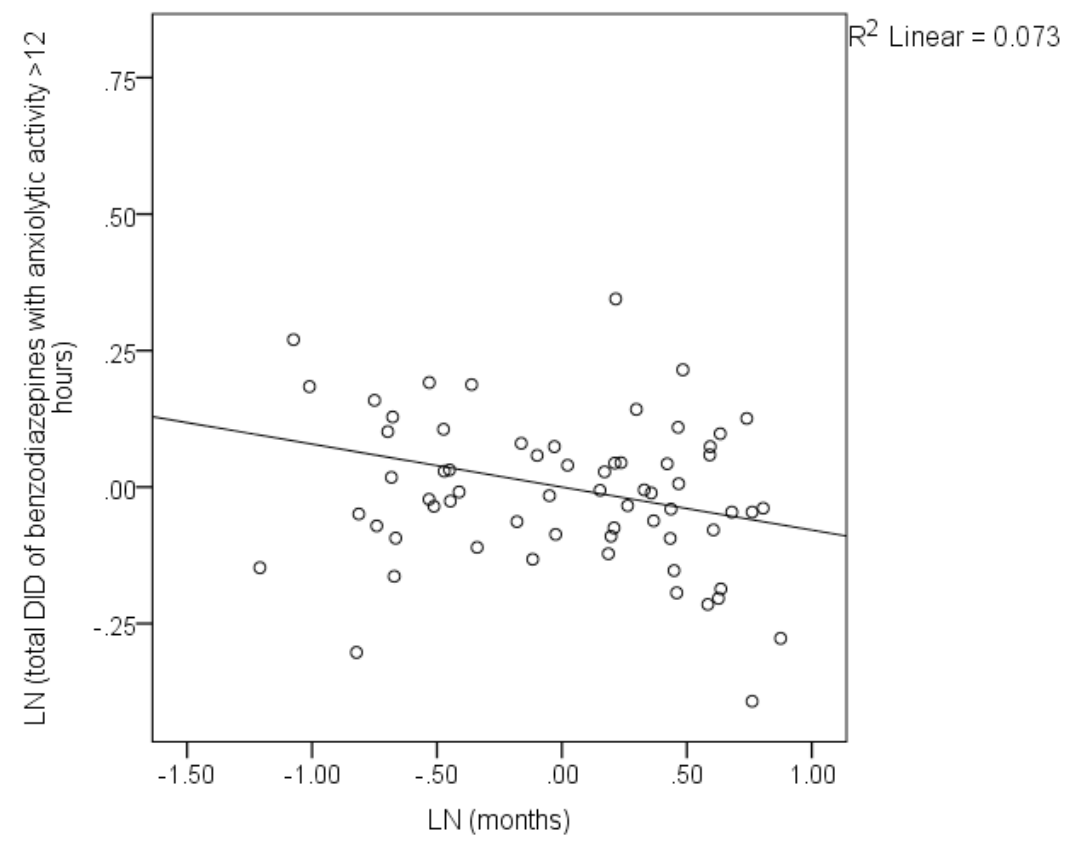

previous study, we found that Serbia recorded a growth trend on a monthly basis in terms of exposure to certain benzodiazepines [2]. We obtained a single valid model with these two significant INDEPENDENT predictors, where only the population exposure to benzodiazepines with anxiolytic action longer than 12 $\mathrm{h}$ as a dependent $(\mathrm{y})$ variable was significantly associated with these mutually independent predictors (LN months / 1 to 65, for the period from January 2014 to May 2019 and LN total number of sunny hours per month in the same period). This model showed that there is a significant positive correlation of logarithmically transformed months, as well as a negative correlation with logarithmically transformed total sundials with population demand for benzodiazepines with anxiolytic action longer than $12 \mathrm{~h}$. We see in this model (Table 4) that the regression coefficients in front of these inde- 
pendent predictors are almost equal, and then we conclude that the strength of the impact of the first independent predictor (economic impacts) is almost equal to the strength of the second independent predictor (seasonal climate impacts) population with benzodiazepines with anxiolytic action longer than 12 h. However, if we look at the coefficients of determination (R2) in the model for the mentioned predictors, we see that economic influences (LN months) determine the dependent variable twice as reliably (DID for benzodiazepines with anxiolytic action longer than 12 hours) than the total number of sunscreens. hours per month.

\section{DISCUSSION}

The essence of research is: This is the first pharmaco-epidemiologic study to prove that exposure of the population to benzodiazepines, in addition to implicit health and economic effects on physicians' prescribing habits for these drugs, can be independently associated with seasonal climatic effects of total monthly sunshine on the population.

The results of our study show that there is no difference in the use of benzodiazepines between the period of theoretically higher insolation in spring/summer compared to the period of autumn / winter (Table 2), which is consistent with the results of other studies [10].

The difference between higher and lower use of benzodiazepines, i.e. bromazepam in our study, was defined by the Cutoff value of 131.45 hours of sunshine per month. The number of hours of sunshine is negatively correlated with the use of benzodiazepines. Studies have shown interesting results on the association of sunshine hours on a weekly basis with serum Brain-Derived Neurotrophic Factor (BDNF) levels, where a significant but low negative correlation was found [11].

This is important, because these results already indicate the rule that the population has a greater need for bromazepam, a benzodiazepine with anxiolytic effect equal to or longer than 12 hours, during those months with total insolation in hours less than 131.45 hours. In other words, the results of our study show that the average population exposure to bromazepam is certainly the highest compared to other benzodiazepines (Table 1), and that the need for this drug in the population increases significantly in months with less insolation (Table 3). This may be one of the reasons why the need for bromazepam increases in the population whose anxiety increases when the cumulative insolation during the month is equal to or falls below 131.45 hours. The difference in the need of the population of the Republic of Serbia for benzodiazepines, despite the found differences in insolation between spring/summer vs autumn / winter months is not significant. Thus, the difference is not related to the season but to the cumulative sunshine during the month. Even sun exposure in the workplace affects the level of anxiety and job satisfaction, with direct sun exposure having a better effect than indirect [12]. Although the length of insolation plays a significant role in the use of benzodiazepines, the authors of this study believe that the influence of other factors on the pharmacotherapy of anxiety should not be neglected.

Since long-acting benzodiazepines can relieve people's problems inversely proportional to cumulative sun exposure, taking into account the result of this research, we can talk about a better quality of life with as few medications as possible. The population that is aware of the impact of sunshine should prefer psychotherapy and perform work tasks more easily, thus laying the groundwork for more technologically advanced work tasks. This makes the whole country more economically promising, which may be the subject of further research.

Recent research indicates an interaction between age and sunshine hourssunshine hours as well as latitude lines [13]. Based on the results of previous research on the effects of various factors on the use of benzodiazepines [5], with additional education and revision of guidelines, it is necessary to precisely define which profile of experts has the right to prescribe this group of drugs $[2,14]$.

\section{CONCLUSION}

This is the second pharmaco-epidemiologic study to prove that the population's exposure to benzodiazepines, can be independently linked to the cumulative effects of monthly insolation on the population.

No difference in benzodiazepine consumption was found in relation to the seasons (spring/summer vs autumn /winter). In months where the insolation is $\geq 135.45$ hours 
per month, the need for bromazepam with an anxiolytic effect longer than 12 hours is significantly reduced.

The variation of climatic effects of total monthly insolation is significantly correlated with the population's need for longer anxiolytic effect bromazepam.

\section{LIMITATIONS}

The limiting factor of this study is that the research covered the territory of only one state, i.e. the Republic of Serbia. However, statistical processing showed that the geographical and climatic position of the Republic of Serbia is representative, that the places were well selected and that further research according to this methodology makes sense and can be extended to a larger geographical territory, which means larger sample. The study was underpowered and the lack of differences in tables 1 and 2 should be ascribed to type 2 statistical error.

\section{ACKNOWLEDGEMENT}

The financial support for this project was provided by the Ministry of Education, Science and Technological Development of the Republic of Serbia contract number: 451-03-9/2021$14 / 200146$.

\section{CONFLICTS OF INTEREST}

All authors declare no conflict of interest.

\section{REFERENCES}

1. Guina J, Merrill B: Benzodiazepines I: Upping the Care on Downers: The Evidence of Risks, Benefits and Alternatives. J Clin Med 2018; 7:17. doi: $10.3390 /$ jcm7020017

2. Marković SZ, Dimitrijević Jovanović NI, Sedić B, Vuković MH, Okjan JJ, Dimitrijević IK, Trikoš LD, Mojović MD, Kastratović DA. Impact of Differences in Economic Development and Socioeconomic Stability on Benzodiazepine Exposure between the Three Balkans Countries. Psychiatr Danub. 2019 Dec;31(Suppl 5):750-760. PMID: 32160168.

3. Gorevski E, Bian B, Kelton CM, Martin Boone JE, Guo JJ. Utilization, spending, and price trends for benzodiazepines in the US Medicaid program: 19912009. Ann Pharmacother. 2012 Apr;46(4):503-12. doi: 10.1345/aph.1Q618. Epub 2012 Mar 27. PMID: 22454448 .

4.Bushnell GA, Stürmer T, Gaynes BN, Pate V, Miller
M. Simultaneous Antidepressant and Benzodiazepine New Use and Subsequent Long-term Benzodiazepine Use in Adults With Depression, United States, 2001-2014. JAMA Psychiatry. 2017 Jul 1;74(7):747755. doi: 10.1001/jamapsychiatry.2017.1273. PMID: 28593281 ; PMCID: PMC5710248.

5. Köhler-Forsberg K, Jorgensen A, Dam VH, Stenbæk DS, Fisher PM, Ip CT, Ganz M, Poulsen HE, Giraldi A, Ozenne B, Jørgensen MB, Knudsen GM, Frokjaer VG. Predicting Treatment Outcome in $\mathrm{Ma}$ jor Depressive Disorder Using Serotonin 4 Receptor PET Brain Imaging, Functional MRI, Cognitive-, EEGBased, and Peripheral Biomarkers: A NeuroPharm Open Label Clinical Trial Protocol. Front Psychiatry. 2020 Jul 23;11:641. doi: 10.3389/fpsyt.2020.00641. PMID: 32792991; PMCID: PMC7391965.

6. Bulbena A, Pailhez G, Aceña, R, Cunillera J, Rius A, Garcia-Ribera C, Gutiérrez J, Rojo C. Panic anxiety, under the weather?. International journal of biometeorology,2005;49(4):238-43. 10.1007/ s00484-004-0236-0.

7. IQIA Institute for Human Data Science. https:// www. iqvia.com/institute

8. "Weather Online" website. https://www.weatheronline.co.uk/weather/maps/forecastmaps?LANG $=e n \& C O N T=e u r o \& R E G I O N=0005 \& L A N D=Y G \& U P=1 \&$ $\mathrm{R}=0 \& \mathrm{CEL}=\mathrm{C}$

9. Statistical Office of the Republic of Serbia. http://data.stat.gov.rs/Home/ Result $/ 18010403$ ?languageC ode $=$ sr-Cyrl

10. Baek JH, Kim JS, Huh I, Lee K, Park JH, Park T, Ha K, Hong KS. Prevalence, behavioral manifestations and associated individual and climatic factors of seasonality in the Korean general population. Compr Psychiatry. 2015 Feb;57:148-54. doi: 10.1016/j.comppsych.2014.10.014

11. Molendijk ML, Haffmans JPM, Bus BAA, Spinhoven P, Penninx BWJH, Prickaerts J, Oude Voshaar RC, Elzinga BM. Serum BDNF Concentrations Show Strong Seasonal Variation and Correlations with the Amount of Ambient Sunlight . PLoS ONE 2012;7(11): e48046. doi:10.1371/journal.pone. 0048046

12. An M, Colarelli SM, O'Brien K, Boyajian ME. Why We Need More Nature at Work: Effects of Natural Elements and Sunlight on Employee Mental Health and Work Attitudes. PLoS One. 2016;11(5):e0155614. Published 2016 May 23. doi:10.1371/journal. pone. 0155614

13. Jaworeck S, Kriwy P. It's Sunny, Be Healthy? An International Comparison of the Influence of Sun Exposure and Latitude Lines on Self-Rated Health. Int J Environ Res Public Health. 2021;18(8):4101. Published 2021 Apr 13. doi:10.3390/ijerph18084101

14. Bushnell GA, Stürmer T, Mack C, Pate V, Miller M. Who diagnosed and prescribed what? Using provider details to inform observational research. Pharmacoepidemiol Drug Saf. 2018 Dec;27(12):1422-1426. doi: 10.1002/pds.4685. Epub 2018 Oct 31. PMID: 30379369; PMCID: PMC6407693. 


\section{Osunčanost i potrošnja benzodiazepina}

Srđan Z. Marković ${ }^{1,2}$, Đura J. Nakarada ${ }^{1}$, Miloš D. Mojović ${ }^{1}$, Mirjana M. Beljić3, Mira H. Vuković́, Dragana A. Kastratović ${ }^{2}$

${ }^{1}$ Fakultet fizičKe hemije Univerziteta Beograd, Centar za fizičku hemiju bioloških sistema; Beograd, Srbija

${ }^{2}$ Klinički centar Srbije, Beograd, Srbija

${ }^{3}$ Apoteka Beograd, Beograd, Srbija

${ }^{4}$ Odeljenje za obezbeđenje kvaliteta, Bolnica Valjevo, Valjevo, Srbija

\section{KRATAK SADRŽAJ}

Uvod: Benzodiazepini pripadaju grupi anksiolitičkih sedativa i najčešće propisivanih lekova na svetu. S obzirom da sve veći broj pacijenata saopštava (report) da su migracijom u osunčanije životne sredine manje anksiozni i da se sveukupno bolje osećaju, autori su napravili ovo pilot istraživanje.

Cilj: Proceniti uticaj kumulativnih sati osunčanosti na dnevnu upotrebu benzodiazepina na mesečnom nivou u Republici Srbiji.

Metodologija: Sproveli smo retrospektivnu akademsku studiju IV faze, kojom smo ispitivali korelaciju između mesečne potrošnje benzodiazepina i ukupnog broja osunčanih sati tokom meseca u Republici Srbiji od januara 2015 do maja 2019.

Rezultati: Prema godišnim dobima nismo našli nikakvu razliku u povećanju izloženosti stanovništva benzodiazepinima. Nađena je razlika u potrošnji bromazepama u odnosu na kumulativnu osunčanost na nivou meseca. Potrošnja bromazepama je u negativnoj korelaciji sa kumulativnim mesečnim brojem osunčanih sati. Cutoff vrednost za bromazepam je 131,45 osunčanih sati kumulativno mesečno.

Zaključak: Ovo je prva farmakoepidemiološka studija kojom je dokazano da se izloženost stanovništva benzodiazepinima nezavisno može povezati i sa kumulativnim uticajima mesečne osunčanosti na stanovništvo. Nije nađena razlika u potrošnji benzodiazepine u odnosu na godišnje doba (proleće/leto vs leto/zima). U mesecima gde je osunčanost $\geq 135,45$ hours na mesečnom nivou, značajno je smanjena potreba za bromazepamom. Sezonsko variranje klimatskih uticaja ukupne mesečne osunčanosti značajno je u negativnoj korelaciji sa potrebom stanovništva za benzodiazepinima sa anksiolitičkim dejstvom dužim od 12 časova.

Ključne reči: benzodiazepini, osunčanost, klima, potrošnja, anksiolitici 